\title{
Migratory Dynamics of Bozo Fishermen on the Rivers of Ivory Coast: The Case of the Bandama River
}

\author{
Kien Kouassi Brahiman ${ }^{1, ~ *}$, Ndiaye Awa ${ }^{1}$, Boguhe Gnonleba Franck Dit Hervis ${ }^{2}$ \\ ${ }^{1}$ Biological Sciences Training and Research Unit, Peleforo Gon Coulibaly University, Korhogo, Ivory Coast \\ ${ }^{2}$ Biosciences Training and Research Unit, Félix-Houphouët-Boigny University, Abidjan, Ivory Coast
}

Email address:

kienkouassibrahima@yahoo.fr (K. K. Brahiman)

${ }^{*}$ Corresponding author

\section{To cite this article:}

Kien Kouassi Brahiman, Ndiaye Awa, Boguhe Gnonleba Franck Dit Hervis. Migratory Dynamics of Bozo Fishermen on the Rivers of Ivory Coast: The Case of the Bandama River. International Journal of Applied Agricultural Sciences. Vol. 7, No. 5, 2021, pp. $232-236$. doi: 10.11648/j.ijaas.20210705.13

Received: September 15, 2021; Accepted: October 11, 2021; Published: October 30, 2021

\begin{abstract}
The mastery of the management of fishery resources and their exploitation strategies on a spatio-temporal scale concerns both scientists and those responsible for the development of the fishing sector. Indeed, the permanent migration of actors prevents better control of the workforce, it does not facilitate the development of an effective management plan for this sector of activity. The present study aims to characterize the spatial and economic movements of Bozo fishermen on the Bandama River. Data was collected from December 2019 to November 2020 from questionnaires and interviews sent to fishermen and direct observation in the field. Analysis of the data showed multiple factors favoring the migratory dynamics of Bozo fishermen. These are the fishing tradition, the strong capitalization of the profession and the exchange of information thanks to the advent of the cell phone. Migration is characterized by daily mobility ( 1 to $24 \mathrm{~h}$ ); seasonal mobility ( 1 to 3 months) and annual mobility (at least 1 year). The consequences of this behavior have resulted in a drop in production, an increase in the purchase price of fish for consumers and a difficult control of the number of fishermen for better management of the sector. This study showed that Bozo fishermen favor spatial mobility in their quest for fishery resources. This strategy gives rise to daily mobility and micro-trips depending on the time spent away from the usual localities. This behavior could lead to the depletion of fishery resources. Thus, vigorous measures must be taken to better control this movement with a view to the sustainable management of this resource.
\end{abstract}

Keywords: Bandama River, Bozo Fishermen, Migratory Dynamics, Ivory Coast

\section{Introduction}

Mobility is the ability to move from one place to another. These spatio-temporal movements generate both the variation in the number of this population and the migrations of inhabitants [1]. Nevertheless, [2] specify that habitual mobility does not imply a break in the usual framework of life. The other displacements with prolonged change of living environment are migrations. Depending on the duration, a migration is said to be daily, seasonal, annual or definitive. Bozo fishermen are the main players in artisanal fishing on the Bandama river. This group is characterized by local, national and international mobility [3]. This mobility is not without consequences because the influx of Bozo fishermen on Lake Ayamé 1, for example, has led to conflicts which have resulted in the expulsion of these fishermen from fishing areas [4]. Moreover, [5] noted the unstable nature of the numbers of Bozo fishermen in the fishing statistics on Lake Buyo.

No study deals with this phenomenon, which considerably influences the establishment of a development plan for the continental artisanal fishery. [6] consider on this subject that the lack of information constitutes a handicap in the implementation of a management plan in any socio-economic sector.

This article was initiated to decipher the migratory 
dynamics of Bozo fishermen to fill this information gap.

\section{Material and Methods}

\subsection{Study Zone}

The study area is located downstream of the Taabo lake on the lower Bandama river. This work was carried out in three localities (Figure 1): Tiassalé ( $5^{\circ} 53 \mathrm{~N}$ and $\left.4^{\circ} 49 \mathrm{~W}\right)$, $\mathrm{N}^{\prime}$ Zianouan $\left(6^{\circ} 00\right.$ and $\left.4^{\circ} 49 \mathrm{~W}\right)$ and Singrobo $\left(6^{\circ} 05 \mathrm{~N}\right.$ and $\left.4^{\circ} 55 \mathrm{~W}\right)$.

\subsection{Data Collection}

As part of the present study, daily monitoring of fishing activities and a survey carried out by repeated passages were carried out in the various localities. This survey took place from December 2019 to November 2020 and took into account all categories of actors. The selection of sites took into account the density of the population and accessibility in all seasons. A questionnaire was then assigned to each of the fishermen and the administrative authorities. This technique was supplemented by a direct conversation with the managers of the water and the fishery. We also carried out direct observations in the field to verify the information received from the fishermen. The various data collected provide information on the periods of influx of fishermen in the different zones, to highlight their mobility from the native country to the localities which welcome them and to decipher the economic situation of the actors before identifying the 'impact of migration practices on their living conditions.

The percentages were obtained by making for each locality and for each category of migrants the number of migrants out of the total number of migrants.

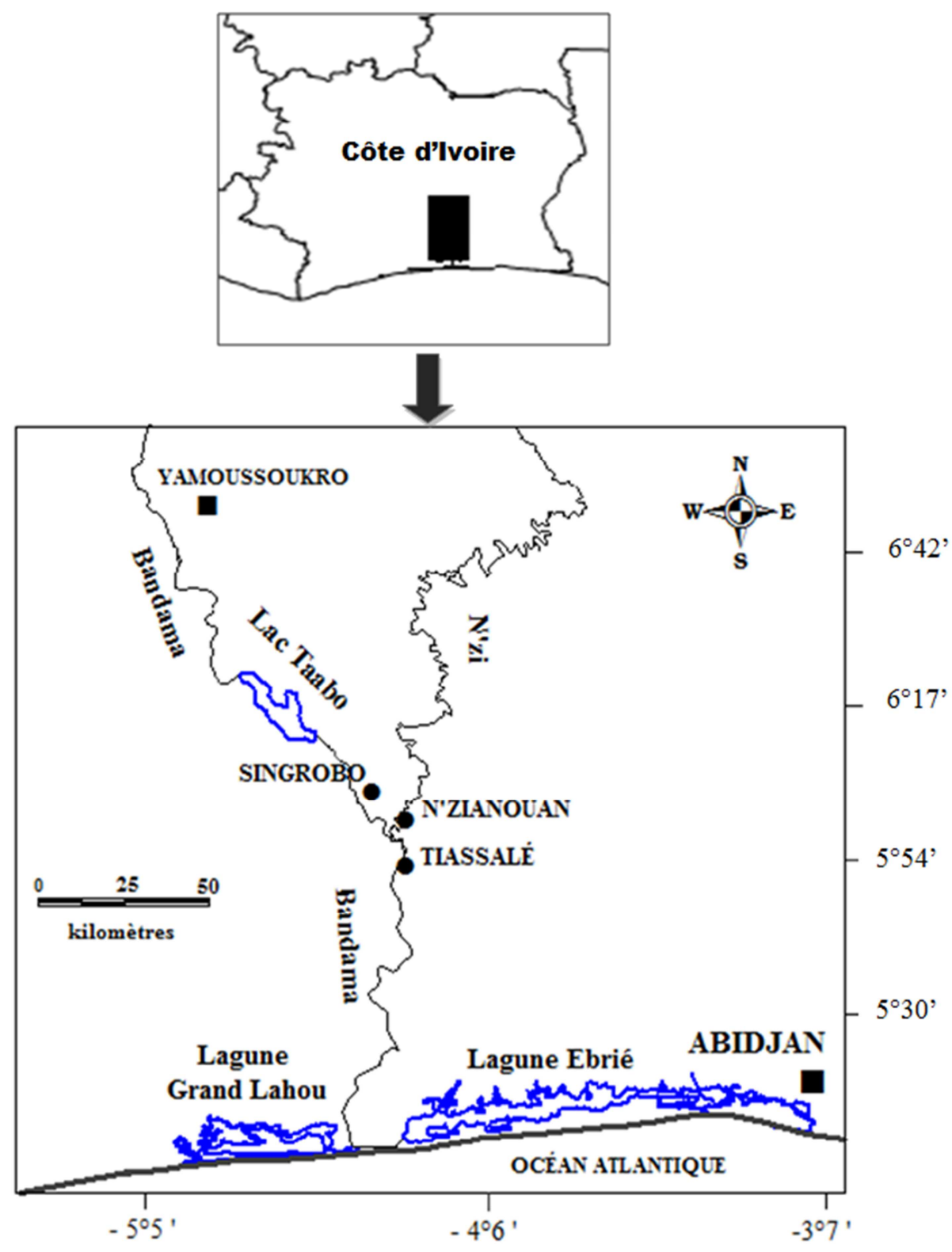

Figure 1. Geographical location of the survey and sampling stations $(\bullet)$ on the lower Bandama river. 


\section{Results}

\subsection{Factors Favoring the Mobility of Bozo Fishermen}

\subsubsection{The Advent of Mobile Telephony in Fishing}

Bozo fishermen exchange information on fishing sites from one place to another on the Bandama river. Decades ago, the exchange of information between fishermen was done by word of mouth or by messages given to travelers. These exchanges of information on fishing are currently being reinforced by the advent of mobile telephony. Thus, each fisherman can be quickly reached by another to invite him to another fishing site. Mobile telephony increases communication between fishing units, always on the lookout for information on fishing grounds.

\subsubsection{The Existence of a Malian Community}

In general, the arrival of a fisherman in an area is favored by parents, friends and acquaintances of the same community already living in that area. This community facilitates the acquisition of habitat and fishing equipment. The community is also helping to quickly prepare documents giving access to the fishing area.

\subsubsection{Profitable Fishing Gear and Techniques than by Itinerant Fishing}

Fishing gear is used depending on the target resource. For example, the capture of large fish such as the genera Lates and Heterotis requires specialization in bottom lines and harpoon while that of the genera Tilapia and Chrysychtys requires mastery of gillnets and conical fishing baskets. The fishermen, faithful to their fishing technique, move to the permanent conquest of new fishing areas in search of the same type of fish.

\subsection{Type of Mobility and Distance from the Farm}

\subsubsection{Types of Fishermen's Mobility}

\section{(i) Economic Mobility}

The drop in fish production and its consequences on the income of fishermen in the Bandama river have led most of them to turn to other sectors of activity. Thus, the Bozo who have a tradition of cultivating temporarily return to their native country during the growing season to start agricultural activities.

They take advantage of these trips to buy agricultural seeds, livestock for breeding or take care of other ancillary economic activities (trade, construction, etc.) that they develop there from the income from fishing.

\section{(ii) Spatial Mobility}

The development of fishing on the lower Bandama river has caused a phenomenon of migration (Table 1). Thus, the majority of Bozo fishermen (85.32\%), active for the most part in certain african countries (Senegal, Mali and Burkina Faso), have migrated to the Bandama river. The rest (14.68\%) migrated from an Ivorian lake to the lower Bandama river. Some fishermen leave the river towards the lakes. There are also movements within the fishing sites of the river.

Table 1. Distribution of fishermen in the lower Bandama river by type of migration. (IV=Ivorian; $N-I=N o n-I v o r i a n)$.

\begin{tabular}{lllllll}
\hline \multirow{2}{*}{ Locality } & \multirow{2}{*}{ Nationality } & \multicolumn{2}{l}{ Migration interstate } & \multicolumn{2}{l}{ Migration for another lake } & \multicolumn{1}{c}{ Total number of fishermen per } \\
\cline { 3 - 5 } locality
\end{tabular}

\subsubsection{Distance from the Field}

The type and duration of the trip depend on the remoteness of the operating field from the home camp, which they assess either in hours or days of canoes, or in liters of fuel consumed, or by transport costs. These variables make it possible to determine different levels of mobility.

Our survey results have shown three levels of mobility motivated by the selection of fishing sites according to the distance traveled and the duration of the fishing trips.

Level 1: Daily mobility carried out over a short distance, with a duration that does not exceed 24 hours. This move does not entail a change of residence. The fishermen quickly return to their bases once the fishing is finished. This type of mobility is preferred by most single fishermen who do not have family responsibilities.

Level 2: Micro-trips that are made during fishing trips. These campaigns are organized when a relatively remote area is determined to be rich in fish. These operational missions therefore require travel but without significant change of residence. However, not being able to return each day to their original residences and leave the next day, the fishermen prefer to settle there for one to three months. Thus, fishermen from the Bandama river find themselves temporarily on the various lakes or other rivers and vice versa.

Level 3: Seasonal or annual migrations which correspond to seasonal or annual migrations. These displacements entail changes of residence and country for at least one year. The annual departures of Bozo fishermen to their native country take place at the start of the rainy season in this country to carry out agricultural activities.

\subsection{Consequences of the Mobility of Fishermen}

The consequences resulting from the movements of fishermen in search of fishery resources have resulted in a drop 
in production on the Bandama river. This mode of resource exploitation suggests an exhaustion of fishery resources and a change in the composition of commercial fishing catches.

Socio-economically, there is an increase in the purchase price of fish for consumers. In addition, it is difficult to control the numbers of fishermen working in each zone for better management of the sector.

\section{Discussion}

The results of the present study showed that the majority of the Bozo fishermen encountered migrated to the Bandama river. The behavior of this group of actors is noted on the various lakes [7, 8] and lagoons [9, 10]. This migration is generally done at the invitation of a friend or fishing relative already installed in the area. Some came from the lakes of Kossou and Taabo, following conflicts between the residents of these lakes and these fishermen from Mali, a country neighboring the Ivory Coast. Others arrived there after hearing about the abundance of the catch or the high profitability of fishing in this area. Likewise, the decline in fish production and its consequences on the income of fishermen are at the basis of the orientation of most of them towards other sectors of activity. These ancillary activities are now considered to be the main economic activities for some fishermen [11]. In addition, the typology of spatio-temporal movements noted in our survey results shows daily mobility, micro-journeys and seasonal migrations with a dominance of levels 1 and 2 . This situation is explained by the fact that the majority fishermen would have settled down in establishments created by their more or less distant ancestors, often well before the respective sovereignty of Mali, native country and Côte d'Ivoire, adoption country [12]. This situation led Delaunay [13-15] to say that these types of fishermen cannot currently be qualified as foreigners but rather as Ivorian fishermen although they remain of the Bozo ethnic group. Understanding and above all mastering these movements are of considerable benefit to the monitoring of continental fishing, the socioeconomic, spatial and environmental implications of which are significant.

\section{Conclusion}

This study showed that for the Bozo people favor spatial mobility in their quest for fishery resources. This strategy gives rise to daily mobility and micro-trips depending on the time spent away from the usual localities. This behavior of these most important actors in the different fishing zones could lead to an exhaustion of fishery resources and a modification of the composition of the catches of commercial fishing. Given the economic interest of fishing in this area in particular and in Côte d'Ivoire in general, vigorous measures must be taken to better control this movement with a view to the sustainable management of this resource.

Thus, the Ivory Coast State will have to:

1. Improve the data collection system on the fishing industry because improving the fishing situation on the Bandama River necessarily requires reliable statistical data on this sub-sector. The State must therefore strengthen the collection system already in place by statistical engineers specializing in fisheries for improved data. The material and financial support of these services is more than necessary today.

2. List the camps and villages, the population and the fishing boats. Thus, the State must absolutely take a census of the camps and villages, the population and the fishing boats in order to assess the numbers and count the canoes.

This will make it possible to have results close to reality over the entire sampled area in terms of production. This work could be done every year, which would allow managers to control the number of fishermen and especially migrants.

Perspective.

Following our study, it would be interesting to move towards the establishment of real policies for monitoring Ivorian ecosystems and the establishment of relevant databases. This approach will allow a better control of the dynamics of the actors on the one hand and of these ecosystems on the other hand.

\section{Acknowledgements}

We would like to thank professional fishers operating on the lower Bandama river for their help and cooperation. We are also grateful to the Fishery Office of Tiassale for providing useful data and assistance.

\section{References}

[1] Derruau M., 2005. Géographie humaine [Human geography]. Arman Colin, huitième édition, Paris, $447 \mathrm{p}$.

[2] Brand D., Durousset M., 1995. Dictionnaire thématique Histoire-Géographie [Thematic dictionary HistoryGeography]. $4^{\mathrm{e}}$ édition, Éditions Dalloz. 11, rue Soufflot, 75240 Paris cedex 05, SIREY, $541 \mathrm{p}$.

[3] Kien K. B; Yao S. S; Vanga A. F et Kouamélan E. P., 2015. Typologie de la peche sur le cours inferieur du fleuve Bandama (Côte d'Ivoire, Afrique de l'Ouest) [Typology of fishing on the lower Bandama river (Ivory Coast, West Africa)]. International Journal of Innovation and Applied Studies, 13 (1): 66-77.

[4] Cissé M.; Kamelan T. M; Kien K. B et Kouamelan E. P., 2019. Fish assemblage composition and fishery production in the man-made lake, West Africa. Journal of fisheries and life sciences, 4 (1): 9-14.

[5] Kien K. B.; Kouamé K. A; N'Da A. S; Vanga A. F; Kouamelan E. P., 2019. Exploitation durable du poisson sur le cours inferieur du fleuve Bandama (Côte d'Ivoire): contraintes et recommandations [Sustainable exploitation of fish in the lower course of the Bandama river (Côte d'Ivoire): constraints and recommendations]. Journal of Applied Biosciences, 125: 12542-12550. 
[6] Goli bi B. E. P.; Kien K. B; Kamelan T. M; Berte S et Kouamelan E. P., 2019. Typologie de la pêche sur le lac de barrage de Buyo (Fleuve Sassandra, Côte d'Ivoire) [Type of fishing on the Buyo lake (Sassandra River, Ivory Coast)]. International Journal of Innovation and Applied Studies, 26 (4): $1220-1229$.

[7] Vanga A. F., 2001. Conséquences socio-économiques de la gestion des ressources naturelles: cas des pêcheries dans les lacs d'Ayamé et de Buyo (Côte d'Ivoire). Thèse de Doctorat, Université d'Abobo-Adjamé, Abidjan, Côte d'Ivoire [Socioeconomic consequences of natural resource management: case of fisheries in Ayamé and Buyo lakes (Ivory Coast) Doctoral Thesis, University of Abobo-Adjamé, Abidjan, Ivory Coast], $210 \mathrm{p}$.

[8] Koudou D., 2012. La pêche sur le lac de Taabo. Thèse de Doctorat, Université Félix HOUPHOUËT-BOIGNY, Abidjan, Côte d'Ivoire [Fishing on Lake Taabo. Doctoral thesis, Félix HOUPHOUËT-BOIGNY University, Abidjan, Ivory Coast], $389 \mathrm{p}$

[9] Diaby M., N'Da K. \& Konan K. S., 2010. La pêche des poissons Mugilidae dans la lagune de Grand-lahou (Côte d'Ivoire): analyse de l'organisation de la pêche, des captures et de l'effort de pêche [Fishing for Mugilidae fish in the Grand-lahou lagoon (Ivory Coast): analysis of the organization of fishing, catches and fishing effort]. Tropicultura, 30 (3): 173-179.

[10] Laë R., 1992. Les pêcheries artisanales lagunaires ouestafricaines: échantillonnage et dynamique de la ressource et de l'exploitation [West African artisanal lagoon fisheries: sampling and dynamics of the resource and exploitation]. ORSTOM, $189 \mathrm{p}$.

[11] Vanga A. F., 2004. Conséquences socio-économiques de l'expulsion des pêcheurs étrangers en Côte d'Ivoire: lacs d'Ayamé et de Buyo [Socio-economic consequences of the expulsion of foreign fishermen in Ivory Coast: lakes of Ayamé and Buyo]. Revue Européenne Des Migrations Internationales, 20 (1): 197-205.

[12] Kouman K. M., 2012. Implantation des pêcheurs dans le Sudouest de la Côte d'Ivoire: permanence et mutation dans l'organisation de l'espace [Establishment of fishermen in the southwest of Côte d'Ivoire: permanence and change in the organization of space]. Editions Universitaires Européennes, Saarbrücken, Germany, 462 p.

[13] Delaunay K., 1991. Approche historique de l'expansion des pêcheurs ghanéens (Fanti et Ewe) sur le littoral ivoirien. In: La recherche face à la pêche artisanale. Research and small-scale fisheries. Tome II [Historical approach to the expansion of Ghanaian fishermen (Fanti and Ewe) on the Ivorian coast. In: Research in relation to artisanal fishing. Research and smallscale fisheries. Volume II]. Symposium international. ORSTOM-IFREMER. Montpellier (France) 3 au 7 juillet 1989, pp 649-656.

[14] Delaunay K. 1994. Etre ivoirien ou artisan pêcheur maritime...: de quelques vicissitudes d'une "spécialisation ghanéenne" en Côte d'Ivoire. In: Crises, ajustements et recompositions en Côte d'Ivoire: la remise en cause d'un modèle. Colloque international 28 novembre 1994- 02 décembre 1994, [To be Ivorian or artisanal maritime fisherman...: of some vicissitudes of a "Ghanaian specialization" in Ivory Coast. In: Crises, adjustments and recompositions in Côte d'Ivoire: the questioning of a model. International colloquium 28 November 1994- 02 December 1994], GIDISCI-Orstom, Abidjan, pp 39-49.

[15] Delaunay K., 1995. Les pêcheurs ghanéens (fanti et ewe) sur le littoral ivoirien: histoire de la pêche piroguière maritime en Côte d'Ivoire au $20^{\mathrm{e}}$ siècle. Thèse de Doctorat, Université de Paris 1, Panthéon-Sorbonne [Ghanaian fishermen (fanti and ewe) on the Ivorian coast: history of maritime pirogue fishing in Ivory Coast in the 20th century. Doctoral thesis, University of Paris 1, Panthéon-Sorbonne], 539 p. 